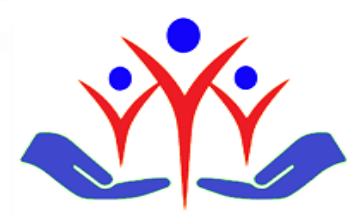

Family Practice and Palliative Care

doi https://doi.org/10.22391/fppc.771580

Research Article

\title{
Knowledge level of nursing home employees on urinary incontinence
}

\author{
Huzurevi çalışanlarının üriner inkontinansa yönelik bilgi düzeyi
}

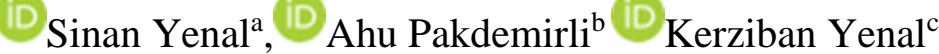 \\ Department of Paramedics, Vocational School of Health Care Services, Dokuz Eylul University, Izmir, Turkey \\ Department of Physiology, Gulhane School of Medicine, University of Health Sciences, Ankara, Turkey \\ Department of Nursing, School of Health, European University of Lefke, Turkish Republic of Northern Cyprus, Turkey
}

\begin{abstract}
Introduction: Urinary incontinence is a common public health problem that increases in frequency with aging. The role of nursing home staff is important in the correct management of this problem. The purpose of this study was to evaluate the level of knowledge about urinary incontinence among healthcare personnel and care workers at nursing homes.

Methods: This descriptive study was conducted with workers caring for the elderly and healthcare personnel working at nursing homes affiliated with the Ministry of Family, Labor and Social Services at the city center of İzmir. The Turkish version of the Incontinence Quiz, for which a Turkish validity and reliability study was conducted by Kara et al., was used as the data collection tool in this study. Data for the study were collected from nursing homes between January and February 2020.

Results: The study was conducted on 205 employees (care workers and healthcare personnel). The mean score of nursing home employees from the Turkish Incontinence Quiz was 6.55 \pm 2.57 . Comparison of the knowledge scores of participants based on their occupation showed that workers caring for the elderly had a lower score than healthcare personnel group $(\mathrm{p}<0.001)$. According to the educational status and number of years worked, university graduates $(\mathrm{p}<0.001)$ and those who had worked for $\geq 16$ years $(\mathrm{p}=0.032)$ had significantly higher scores.

Conclusion: This study showed that nursing home employees had moderate level of knowledge about urinary incontinence. Moreover, education and experience were associated with a higher level of knowledge.
\end{abstract}

Keywords: Caregivers, aged, knowledge, urinary incontinence, nursing homes

\section{$\ddot{\text { Ozz }}$}

Giriş: Üriner inkontinans yaşlanma ile sıklığı artan ve yaygın olarak görülen bir toplum sağlığı sorunudur. Bu sorunun doğru yönetilmesinde huzurevi çalışanlarının rolü önemlidir. Bu çalışmanın amacı huzurevinde çalışan sağlık personeli ve hasta bakım personelinin üriner inkontinans hakkındaki bilgi düzeyini değerlendirilmektir.

Yöntem: Tanımlayıcı türde planlanan araştırma, İzmir il merkezi, Aile, Çalışma ve Sosyal Hizmetler Bakanlı̆̆ huzurevlerinde görev yapan, yaşlı bakım ve sağlık personeli üzerinde yapılmıştır. Veri toplama aracı olarak Kara ve ark. tarafından geçerlik ve güvenirlik çalışması yapılmış olan Turkish Incontinence Quiz kullanılmıştır. Çalışma için veriler Ocak-Şubat 2020 tarihleri arasında huzurevlerinden toplanmıştır.

Bulgular: Araștırma 205 personel (bakım ve sağlık personelleri) üzerinde yapılmıștır. Huzurevi personeli Turkish Incontinence Quiz puan ortalaması 6,55 2,57'dir. Katılımcıların mesleklerine göre bilgi puanları karşılaştırıldığında; yaşlı bakım personelinin puanının sağlık personeli grubuna göre düşük olduğu görülmüştür $(p<0,001)$. Eğitim ve çalışma yılına göre, üniversite mezunu $(p<0,001)$ ve 16 yıl ve üzeri çalışan grubun ( $\mathrm{p}=0,032)$ puanının anlamlı ölçüde yüksek olduğu bulunmuştur.

Sonuç: Bu çalışma huzurevi çalışanlarının üriner inkontinans bilgi düzeyinin orta seviyede olduğunu göstermiştir. Eğitim ve deneyimli olmanın bilgi düzeyini arttırdı̆̆ bulunmuştur.

Anahtar kelimeler: Bakım personeli, yaşl, bilgi, üriner inkontinans, huzurevi

\begin{tabular}{|c|c|c|c|c|}
\hline Received & Accepted & Published Online & Corresponding Author & E-mail \\
\hline July 19, 2020 & September 29, 2020 & September 30, 2020 & Sinan Yenal & sinan.yenal@deu.edu.tr \\
\hline Correspondence & $\begin{array}{l}\text { Sinan Yenal, Dokuz Eylul University, Vocational School of Health Care Services, Department of } \\
\text { Paramedics, Balcova, Izmir, Turkey }\end{array}$ \\
\hline
\end{tabular}




\section{Introduction}

Urinary incontinence (UI), defined as any uncontrolled leakage of urine regardless of the amount, is a primary public health concern [1,2]. According to the population-based prevalence studies conducted in Turkey, the prevalence of UI is particularly higher among older women and ranges from $16.4 \%$ to $49.7 \%$ [3,4]. Nitti showed that in elderly women in the USA, the prevalence of UI ranged from 30\% to 50\% [5]. Hunskaar et al. showed that the prevalence of UI in females was 23\% in Spain, $41 \%$ in Germany, $42 \%$ in the UK, and 44\% in France [6]. Although different results have been reported in studies about UI prevalence, advanced aged was associated with higher prevalence of UI in all previous studies.

Studies have also shown that UI was not perceived as a health concern and accepted as a natural consequence of aging by the general population. The diagnosis and treatment processes are delayed due to the perception of UI as a social problem rather than a health concern. Bilgili et al. found that only $41.4 \%$ of older women visited a physician because of UI [7]. According to another study by Baykuş and Yenal, only $27 \%$ of women who had UI presented to a healthcare facility [4]. Hunskaar et al. highlighted the fact that $31 \%$ of the women received consultation about UI and only visited a physician when they realized that they could not cope with the problem any further because of advanced age and increasing health issues [6]. Therefore, the knowledge and awareness about UI among care workers and healthcare personnel working at nursing homes play a crucial role in solving the problem. When nursing home employees are knowledgeable and well equipped in terms of UI, they are able to guide older adults appropriately and help enhance the quality of life among these individuals [8].

Few studies have investigated the knowledge and practices of caregivers and healthcare personnel about UI. Yenişehir et al. demonstrated that nursing home care workers had insufficient knowledge about UI [9]. Saxer et al. showed that the practices of nurses and nursing assistants working at nursing homes were inadequate with respect to the care of patients with UI [10]. Jang et al. showed that healthcare personnel had moderate level of knowledge about UI [11].

The prevention and treatment of UI, a common health concern that may have a negative impact on quality of life, requires multidisciplinary teamwork. Therefore, there is a need to assess the knowledge and attitudes of nursing home employees toward UI. This study was designed to evaluate the level of knowledge about UI among healthcare personnel and care workers at nursing homes.

\section{Methods}

\section{Study participants}

This descriptive study was conducted at six nursing homes affiliated with the Ministry of Family, Labor and Social Services at the city center of İzmir. The study population included all the healthcare workers caring for the elderly at these nursing homes. Individuals who did not agree to participate in the study and those who were not at the nursing home at the time of the study were excluded. Of the 295 personnel that constituted the study population, 205 [69.5\%) could be reached and were enrolled.

\section{Study procedures}

The Turkish Incontinence Quiz (IQ) that was developed by Branch et al. and for which a Turkish validity and reliability study was conducted by Kara et al. (2017), was used as the data collection tool. The IQ consists of 14 items, and the participants were asked to answer each item using the following options: "Agree," "Disagree," and "Do not know." The correct answer was "Agree" for the $1^{\text {st }}, 4^{\text {th }}, 6^{\text {th }}, 8^{\text {th }}, 10^{\text {th }}$, and $11^{\text {th }}$ items and "Disagree" for the $2^{\text {nd }}, 3^{\text {rd }}, 5^{\text {th }}, 7^{\text {th }}, 9^{\text {th }}, 12^{\text {th }}, 13^{\text {th }}$, and $14^{\text {th }}$ items. Items marked as "Do not know" were considered incorrect. Each correct answer was assigned one point, and the total score ranged from 0 to 14, where higher scores indicated a higher level of knowledge about UI [12]. Although the Turkish IQ was shown valid and reliable in Turkish for women, it was also administered to caregivers by Yenişehir et al. [9].

An additional form was prepared to evaluate the personal information of the participants. This form was used to collect data by the investigator between January 2020 and February 2020 at the nursing homes. Nursing home employees were informed about the study, and those who volunteered to participate were included. Written consent was obtained from all the participants.

\section{Statistical analysis}

Data was evaluated using "SPSS (SPSS Inc., Chicago, IL, USA) for Windows 18.0". Descriptive statistics, Mann-Whitney U test, and KruskalWallis one-way analysis of variance were used as the methods of analysis.

\section{Ethical approval}

This study was approved by the Non-interventional Research Ethics Committee of Dokuz Eylül University with the decision number 2019/29-06, dated December 02, 2019, and protocol no. 5124-GOA.

\section{Results}

The mean age of the enrolled nursing home employees was $40.44 \pm 7.09$ years (range 21-64 years). Table 1 shows the sociodemographic characteristics of the nursing home employees who participated in the study. 
Table 1. Sociodemographic characteristics of the participants $(n=205)$

\begin{tabular}{lccc}
\hline & $\mathbf{n}$ & $\% *$ & $\bar{X} \pm \mathrm{S}$ \\
\hline $\begin{array}{l}\text { Sex: } \\
\quad \text { Female }\end{array}$ & 136 & 66.35 & $40.27 \pm 6.85$ \\
$\quad$ Male & 69 & 33.65 & $40.80 \pm 7.60$ \\
Occupational status: & & & \\
$\quad$ Care worker & 135 & 65.85 & $41.84 \pm 6.19$ \\
$\quad$ Healthcare personnel & 70 & 34.15 & $37.97 \pm 7.89$ \\
Education: & & & \\
$\quad$ Elementary School & 20 & 10.20 & $44.16 \pm 6.67$ \\
$\quad$ Secondary School & 35 & 17.85 & $41.86 \pm 6.57$ \\
$\quad$ High School & 91 & 46.43 & $39.24 \pm 6.89$ \\
$\quad$ University & 50 & 25.52 & $40.27 \pm 7.54$ \\
Number of years worked: & & & \\
$\quad \leq 5$ years & 37 & 18.87 & $37.71 \pm 8.78$ \\
6-10 years & 57 & 29.09 & $39.33 \pm 8.64$ \\
11-15 years & 75 & 38.27 & $42.26 \pm 5.12$ \\
$\quad \geq 16$ years & 27 & 13.77 & $41.52 \pm 3.94$ \\
Received training on UI** & & & \\
$\quad$ Yes & 81 & 41.11 & $39.47 \pm 6.68$ \\
No & 116 & 58.89 & $41.18 \pm 7.37$ \\
\hline
\end{tabular}

*Column percentage $* *$ Urinary incontinence

Table 2 shows the IQ results of the participants. The highest rate of correct answers was achieved in the following statements: "There are exercises that can help control the bladder if one leaks when they cough, sneeze, or laugh." (Item 6) and "Women are more likely to develop urinary incontinence than men." (Item 4). The highest rate of incorrect/false answers was observed in the statements "Many over-the-counter medications may cause involuntary urine loss." (Item 11) and "Most physicians ask their older patients whether they have bladder control problems." (Item 13).

Table 2. Incontinence Quiz results of the participants $(n=205)$

\begin{tabular}{|c|c|c|c|c|c|}
\hline \multirow{2}{*}{ No } & \multirow{2}{*}{ Question } & \multicolumn{2}{|c|}{ True } & \multicolumn{2}{|c|}{ False } \\
\hline & & $\mathrm{n}$ & $\% *$ & $\mathbf{n}$ & $\% *$ \\
\hline 1 & Most people who currently have involuntary urine loss have normal lives. & 142 & 69.26 & 63 & 30.74 \\
\hline 2 & $\begin{array}{l}\text { Involuntary loss of urine, often called leaky bladder or urinary incontinence, is one of the results of } \\
\text { normal aging. }\end{array}$ & 68 & 33.17 & 137 & 66.83 \\
\hline 3 & $\begin{array}{l}\text { Most people will involuntarily or accidentally lose control of their bladder on a regular basis by the } \\
\text { time they are } 85 \text {. }\end{array}$ & 67 & 32.68 & 138 & 67.32 \\
\hline 4 & Women are more likely to develop urinary incontinence than men. & 153 & 74.63 & 52 & 25.37 \\
\hline 5 & Other than pads, diapers, and catheters, little can be done to treat or cure involuntary urine loss. & 98 & 47.80 & 107 & 52.20 \\
\hline 6 & There are exercises that can help control urine if one leaks when they cough, sneeze, or laugh. & 166 & 80.97 & 39 & 19.03 \\
\hline 7 & The best treatment for involuntary urine loss is usually surgery. & 87 & 42.43 & 118 & 57.57 \\
\hline 8 & $\begin{array}{l}\text { Many people with involuntary urine loss can be cured and almost everyone can experience } \\
\text { significant improvement. }\end{array}$ & 73 & 35.60 & 132 & 64.40 \\
\hline 9 & $\begin{array}{l}\text { Once people start to lose control of their bladder on a regular basis, they usually never regain } \\
\text { complete control over it again. }\end{array}$ & 114 & 55.60 & 91 & 44.40 \\
\hline 10 & Involuntary loss of urine can be caused by several easily treatable medical conditions. & 112 & 54.63 & 93 & 45.37 \\
\hline 11 & Many over-the-counter medications can cause involuntary urine loss. & 26 & 12.68 & 179 & 87.32 \\
\hline 12 & Involuntary urine loss is caused by only one or two conditions. & 132 & 64.39 & 73 & 35.61 \\
\hline 13 & Most physicians ask their older patients whether they have bladder control problems. & 43 & 20.97 & 162 & 79.03 \\
\hline 14 & Most people with involuntary urine loss talk to their doctors about it. & 61 & 29.75 & 144 & 70.25 \\
\hline
\end{tabular}

*Row percentage

The mean score of the nursing home employees in the IQ was $6.55 \pm 2.57$. This implies that the participants had moderate level of knowledge about UI. Table 3 shows the comparison of the sociodemographic characteristics and IQ scores of the participants. Comparison of the IQ scores according to the occupational status of the participants showed that workers caring for the elderly had lower scores than healthcare personnel $(p<0.001)$. According to the educational status and number of years worked, university graduates $(p<0.001)$ and those who had worked for $\geq 16$ years $(\mathrm{p}=0.032)$ received significantly higher scores from the IQ. 
Table 3. Comparison of the sociodemographic characteristics and Incontinence Quiz scores of the participants $(n=205)$.

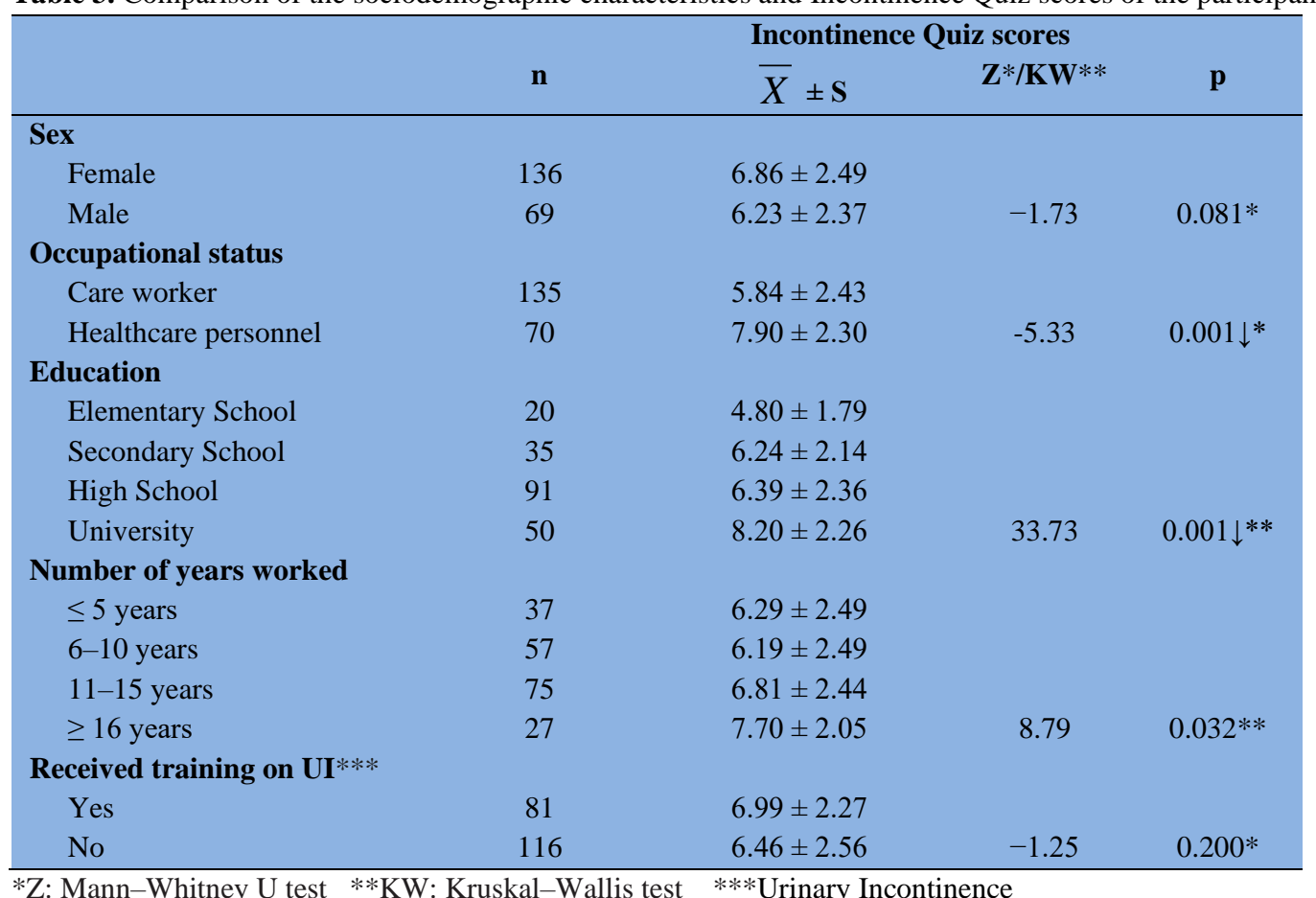

\section{Discussion}

This study is important because it is one of the few studies that have evaluated the level of knowledge about UI among nursing home employees. In this study, the participants received a moderate mean score $(6.55 \pm 2.57)$ in the IQ. Yenişehir et al. used the same scale on nursing home care workers and reported an IQ score of $5.5 \pm 2.0$ [9]. Saxer et al., it was found that the nurses and nursing assistants working at a nursing home scored 12.0 and 10.1 points, respectively, (maximum score 18) in a scale on the knowledge about UI [10]. Jang et al. reported a UI knowledge score of $14.6 \pm 2.1$ (maximum score 18) among healthcare personnel [11]. Yuan et al. reported a score of $20.7 \pm 3.5$ (maximum score 30) regarding UI knowledge in nurses working in China [13]. Our findings were generally consistent with previous reports.

Care workers' IQ scores were found to be lower than healthcare personnel. In addition, university graduates and those who had worked for $\geq 16$ years had higher scores. Jang et al. found that physicians had a higher level of knowledge than other healthcare personnel [11]. Saxer et al. demonstrated a very strong connection between education, experience, and knowledge level [10]. Yuan found that educational status and number of years worked did not correlate with the level of knowledge about UI [13]. Apart from one study, it was observed that education and experience contributed positively to the level of knowledge. It is expected that the level of UI knowledge will increase as education and experience increase.

The highest rate of correct answers was observed in the $1^{\text {st }}, 4^{\text {th }}, 6^{\text {th }}$, and $12^{\text {th }}$ items of the IQ. Considering the statements in the relevant items, we concluded that the participants knew that people who have involuntary loss of urine can live normal lives, the prevalence of UI is higher among women, there are exercises that can help improve bladder control, and that there are various causes of involuntary urine loss. Yenişehir et al. showed that the highest rate of correct answers was observed in the $1^{\text {st }}, 4^{\text {th }}$, and $6^{\text {th }}$ items [9]. Workers who cared for the elderly knew about the causes of UI and that UI could be prevented with exercises. Knowledge about the causes of the problem is necessary for caregivers to be able to identify the risk groups beforehand. The prevalence of UI can be reduced when people know that bladder control can be achieved by exercises.

The highest rate of false answers was observed in the $3^{\text {rd }}, 11^{\text {th }}, 13^{\text {th }}$, and $14^{\text {th }}$ items of the IQ. We concluded that the participants had incorrect knowledge on these items because they believed that involuntary urine loss was normal in the elderly, that those who had UI shared their problem with their physician, and that the participants did not realize that over-the-counter medications could cause UI. It is noteworthy that as per Yenişehir et al., the highest rate of false answers was observed in the $13^{\text {th }}$ and $14^{\text {th }}$ items [9]. The fact that some caregivers consider UI a natural part of aging process is an important problem. Many previous studies have showed that individuals did not present to a healthcare facility because they believed that UI was normal, and they were embarrassed to visit the physician. Demirel and Akın showed that $64.8 \%$ of the older women who had UI did not visit their physician [14]. Therefore, the knowledge level of caregivers about UI is crucial for correctly guiding older adults [4,7,15,16].

\section{Limitations}

This study has certain limitations. The Turkish IQ was reliable and valid in women and was not intended for healthcare personnel and care workers. Another limitation was that the results cannot be generalized because the study was conducted in Izmir.

\section{Conclusion}

This study showed that nursing home employees had moderate level of knowledge about UI. Care workers' IQ scores were found to be lower than healthcare personnel. In addition, university graduates and those who had worked for $\geq 16$ years had a high score. Therefore, increasing awareness 
among nursing home employees by improving the existing knowledge and practices and providing continued training on UI is crucial for appropriately guiding elderly subjects with UI.

Conflict of interest: The authors declare that they have no conflict of interest.

\begin{tabular}{|c|r|l|}
\hline \multicolumn{2}{|l|}{ Author Contributions } & Author Initials \\
\hline SCD & Study Conception and Design & SY, AP \\
\hline AD & Acquisition of Data & SY, AP \\
\hline AID & Analysis and Interpretation of Data & SY, KY \\
\hline DM & Drafting of Manuscript & SY, AP, KY \\
\hline CR & Critical Revision & SY, KY \\
\hline
\end{tabular}

Financial support: None

\section{References}

1. Lapitan M, Carmela M. Epidemiology of urinary incontinence, In: Badlani GH, Davila GW, Michel MC, Rosette JJMCH (editors). Continence current concepts and treatment strategies. London: British Library Cataloguing in Publication, 2009;3-13

2. Abrams P, Cardozo L, Fall M, Griffiths D. Rosier P. Ulsmten U, et al. The standardization of terminology of lower urinary tract function: Report from the standardization sub-committee of the international continence society. Neurourol Urodynmics. 2002;21(2):167-78. https://doi.org/10.1016/s0090-4295(02)02243-4

3. Kocak I. [Urinary incontinence prevalence] (in Turkish). In: Onur R, Bayrak O (editors). Urinary incontinence diagnosis and treatment. İstanbul: Nobel medical bookstores, 2015;67-75

4. Baykus O, Yenal K. Prevalence of urinary incontinence in women aged 18 and over and affecting factors. J Women Aging. Published online:22 Oct 2019 https://doi.org/10.1080/08952841.2019.1682923

5. Nitti VW. The prevalence of urinary incontinence. Rev Urol 2001;3(Suppl 1):2-6. https://www.ncbi.nlm.nih.gov/pmc/articles/PMC1476070/

6. Hunskaar S, Lose G, Sykes D, Voss S. The prevalence of urinary incontinence in women in four European countries. BJU Int 2004;93(3):32430. https://doi.org/10.1111/j.1464-410X.2003.04609.x

7. Bilgili N, Akin B, Ege E, Ayaz S. [Prevalence of urinary incontinence and affecting risk factors in women] (in Turkish). Turk Clin J Health Sci 2008;28(4):487-93. https://dergipark.org.tr/tr/pub/gumussagbil/issue/23826/253834

8. Hunter KF, Wagg ASS. Improving nurse engagement in continence care. Nurs Res Rev 2018;8:1-7. https://doi.org/10.2147/NRR.S144356

9. Yenisehir S, Karakaya IC, Karakaya MG. Knowledge and practice of nursing home caregivers about urinary incontinence. Eur Geriatr Med 2019;10(1):99-105. https://doi.org/10.1007/s41999-018-0129-0

10. Saxer S, Bie RA, Dassen T, Halfens RJ. Nurses' knowledge and practice about urinary incontinence in nursing home care. Nurse Educ Today 2008;28:926-34. https://doi.org/10.1016/j.nedt.2008.05.009

11. Jang Y, Kwon BE, Kim HS, Lee YJ, Lee S, Kim SJ, et al. Knowledge and practice behaviors regarding urinary incontinence among Korean healthcare providers in long-term care hospitals. Int Neurourol J 2015;19(4):259-64. http://dx.doi.org/10.5213/inj.2015.19.4.259

12. Kara KC, Karakaya IC, Tunali N, Karakaya MG. Reliability and validity of the Incontinence Quiz-Turkish version. J Obstet Gynecol Res 2018;44(1):144-50. https://doi.org/10.1111/jog.13469

13. Yuan H, Williams BA. Knowledge of urinary incontinence among Chinese community nurses and community-dwelling older people. Health Soc Care Community 2010;18(1):82-90. https://doi.org/10.1111/j.1365-2524.2009.00876.x

14. Demirel T, Akin B. Prevalence and risk factors of urinary incontinence and its impact on quality of life among 65 years and over women who lived in rural area. Turk J Geriatrics 2014;17(4):379-88. http://geriatri.dergisi.org/abstract.php?lang=en\&id=850

15. Kok G, Senel N, Akyuz A. [Determination of the awareness level of the women over 20 years old who attended to GMMA Gynecology Outpatient Clinics in terms of urinary incontinence] (in Turkish). Gulhane Med J 2006;48(3):132-6. http://gulhanemedj.org/archives/archivedetail/article-preview/determination-of-the-awareness-level-of-the-women-/33034

16. Ministry of health, Singapore. Nursing management of patients with urinary incontinence [e-book] MOH Nursing Clinical Practice Guidelines; 2003. Available Date: May 15,2020) 